\title{
RANCANG BANGUN PENGARSIPAN BEBAN KERJA UNTUK JENJANG JABATAN AKADEMIK DENGAN METODE RUP (STUDI KASUS PADA STMIK WIDURI)
}

\author{
Agus Budiyantara ${ }^{1}$, Nurnawaningtyas Pusparini ${ }^{2}$ \\ 1,2 Teknik Informatika, STMIK WIDURI \\ Email: ${ }^{1}$ agusbudiyantara@yahoo.co.id, ${ }^{2}$ tyaspusparini@yahoo.com
}

\begin{abstract}
Dosen adalah salah satu komponen penting didalam suatu sistem pendidikan perguruan tinggi , Karena fungsi seorang dosen sangat penting, maka pemerintah menetapkan mengenai jabatan fungsional dosen dan angka kreditnya yang disebut jabatan akademik. Untuk menentukan angka kredit terdapat beberapa unsur Tri Dharma yang meliputi Pengajaran, Penelitian dan Pengabdian Masyarakat. Jabatan fungsional dosen dibuat sebagai tanda penghargaan, pengakuan dan kepercayaan atas kinerja, integritas dan tanggung jawab dosen. Namun permasalahan timbul ketika dosen yang akan mengurus jenjang jabatan akademik terhambat oleh masalah administrasi. Peneliti memilih STMIK Widuri sebagai obyek penelitian karena hingga saat ini STMIK Widuri tidak memiliki pengarsipan yang baik untuk dokumen para dosennya ketika akan mengurus jenjang jabatan akademik, tidak adanya kejelasan untuk jalur karir dosen, informasi mengenai jenjang jabatan akademik tidak disosialisasikan secara baik, sehingga pemahaman mengenai pentingnya jenjang jabatan akademik tidak ketahui oleh semua dosen, tingginya tingkat ketidakhadiran dosen dalam perkuliahan, dosen sering keluar masuk atau turn over yang berpengaruh kepada akuntabilitas perguruan tinggi. Untuk memecahkan permasalah diatas, peneliti melakukan tinjauan pustaka, pengumpulan data yang meliputi wawancara, observasi, analisis data dengan menggunakan RUP (Rational Unified Process), merancang model, membangun prototype dan pengujian dilakukan dengan cara metode user acceptance test. Dan hasil yang diharapkan dari sistem ini adalah mengatasi permasalahan mengenai kinerja dosen untuk jenjang jabatan akademik di STMIK Widuri.
\end{abstract}

Kata Kunci: Dosen, STMIK Widuri,Metode RUP,Pengarsipan 


\section{PENDAHULUAN}

Salah satu komponen penting didalam suatu sistem pendidikan perguruan tinggi adalah dosen, maka oleh pemerintah menetapkan mengenai jabatan fungsional dosen

dan angka kreditnya yang disebut jabatan akademik dosen dimana pemerintah memutuskan bahwa kedudukan seorang dosen menunjukkan tugas, tanggung jawab, wewenang, hak dalam satuan pendidikan tinggi yang dalam pelaksanaanya berdasarkan pada keahlian tertentu serta bersifat mandiri yang sangat dengan jelas telah diatur dalam Peraturan Mendikbud Republik Indonesia yang telah menetapkan tentang Petunjuk Teknis Pelaksanaan Penilaian Angka Kredit Jabatan Fungsional Dosen dengan nomor 92 tahun 2014 (kelembagaan.ristekdikti.go.id, 2014).

Dari semua penjelasan diatas yang diperkuat dengan adanya Undang- Undang serta Peraturan Pemerintah, maka oleh sebab itu pemerintah memberikan penghargaan atas prestasi kerja seorang dosen dalam bentuk pemberian kenaikan jabatan akademik. Namun untuk proses kenaikan jabatan akademik, pemerintah melakukan yang namanya penilaian. Tim penilai jabatan akademik dosen ialah tim yang dibentuk dan juga ditetapkan oleh pejabat yang berwenang saat itu dan yang bertugas menilai prestasi kerja jabatan akademik dosen.

Untuk menentukan angka kredit dari seorang dosen terdapat unsur kegiatan yang akan dinilai diantaranya unsur utama meliputi pendidikan seperti mengajar, penelitian dan pengabadian masyarakat. Sedangkan untuk unsur penunjang seperti kegiatan di dalam pelaksanaan tugas pokok seorang dosen seperti mengikuti pelatihan, seminar dan lain-lain.

Untuk memecahkan permasalah diatas, peneliti melakukan tinjauan pustaka, pengumpulan data yang meliputi wawancara, observasi, analisis data dengan menggunakan RUP (Rational Unified Process), merancang model, membangun prototype dan pengujian dilakukan dengan cara metode user acceptance test.

\section{Metode Penelitian}

Penelitian ini, peneliti menggunakan jenis penelitian kualitatif. Dengan menggunakan penelitian kualitatif, peneliti dapat melihat obyek yang akan diteliti. Peneliti mendekrispsikan apa yang dilihat, didengar, dirasakan dan apa yang ditanyakan, sehingga di dalam mengumpulkan data terjadi interaksi antara peneliti dengan sumber data. Peneliti dilakukan di Perguruan Tinggi STMIK Widuri Jakarta. Teknik pengumpulan data dilakukan dengan cara wawancara terhadap narasumber, observasi langsung dan studi pustaka untuk merancang model knowledge management system yang relevan. Untuk tahap pengujian sistem, metode user acceptance test digunakan unutk mengetahui apakah sistem yang dirancang dapat diterima dengan baik atau tidak oleh user.

Untuk menunjang penerapan knowledge management system, maka dibutuhkan infrastruktur teknologi informasi yang ada di perguruan tinggi. Dengan adanya infrastruktur yang baik dapat membantu dalam perancangan knowledge management system dan pemanfaatan penerapan KMS dapat meningkatkan budaya sharing knowledge antar dosen di STMIK Widuri.

\subsection{Teknik Analisis}

Penulis menggunakan SECl model, dikarenakan knowledge bukan hanya dalam bentuk tertulis atau terekam dalam explicit, namun bisa juga dalam tacit knowledge. Dengan model SECI merubah pengetahuan tacit menjadi eksplisit maupun sebaliknya yang berguna untuk pengembangan sistem.

\subsection{Teknik Perancangan Sistem}

Penulis menggunakan metode prototype untuk metode pengembangan sistem yang disesuikan dengan pendekatan metode Object Oriented Design atau perancangan berorientasi objek menggunakan Unified Modelling Language (UML).

\subsection{Teknik Pengujian Sistem}

Pada tahap pengujian dilakukan dengan metode user acceptance test. Diharapkan dengan metode ini akan memperoleh hasil yang baik dan akurat dari para responden. Pengujian adalah sebuah proses evaluasi dari sistem untuk mengetahui apakah sistem sudah sesuai dengan kebutuhan user.

\section{Hasil dan Pembahasan}

\subsection{Analisis Sistem}

Pada tahapan analisis, sistem yang sedang berjalan dipelajari dan sistem pengganti diusulkan. Analisis sistem akan menjawab pertanyaan apa yang akan dikerjakan oleh sistem, siapa yang akan menggunakan sistem, kapan dan dimana sistem akan digunakan. Pada tahapan analisis sistem yang berjalan dilakukan dengan pendekatan analisis berorientasi objek untuk sistem yang dirancang, dan menitikberatkan pada kebutuhan fungsional sistem yang berjalan. Dengan Use Case Diagram, Activity Diagram, dan Sequence Diagram hasil dari analisis akan divisualisasikan serta didokumentasikan untuk mewakili keseluruhan 
sistem yang berjalan agar dapat dimengerti oleh pengguna.

Pada tahapan analisis sistem yang berjalan dilakukan sebuah analisa terhadap kondisi dari proses atau kegiatan pada STMIK Widuri. Berdasarkan hasil wawancara dan observasi, diperoleh data dan dokumen yang terkait pada proses jabatan akademik. Dari hasil analisis ini akan menentukan langkah yang akan dilakukan selanjutnya dalam mengembangkan knowledge management untuk menunjang pencapaian jabatan akademik agar kualitas dosen dapat terpantau dengan baik.

Dalam melakukan analisa, proses yang penting adalah bagaimana proses pencapaian beban kerja dosen untuk memperoleh jabatan akademik yang sesuai dengan Tri Dharma.

Dari hasil pengamatan dan analisa proses bisnis saat ini dimulai dari dosen mengumpulkan berkas untuk melengkapi beban kerja yang sesuai dengan ketentuan dan pengalaman dari dosen lain. Pada tahapan ini dosen yang akan mengurus jabatan akademik sering kali bingung mengenai apa saja yang harus dilengkapi dan apa yang harus dilakukan, hal ini dikarenakan minimnya informasi yang diketahui, pihak perguruan tinggi juga tidak melakukan sosialisasi kepada para dosen mengenai pengurusan jabatan akademik. Karena minimnya informasi yang diberikan dan yang diketahui, dosen melakukan penilaian sendiri mengenai kinerjanya selama mengajar, padahal penilaian dosen seharusnya dilakukan oleh pihak perguruan tinggi. Berdasarkan hasil observasi, diketahui bahwa evaluasi terhadap penilaian kinerja dosen didapat dari kuisoner yang diisi oleh mahasiswa saja, sedangkan untuk penilaian kinerja dosen meliputi banyak unsur. Hasil dari Kuisoner mahasiswa untuk penilaian dosen yang telah di isi tidak diolah kembali oleh perguruan tinggi untuk menjadi referensi selanjut dan kuisoner dilakukan karena rutinitas ketika menjelang pelaksanaan ujian akhir semester.Pada langkah selanjutnya setelah dosen yang bersangkutan melakukan penilaian sendiri atas prestasi kerjanya dengan mengisi angka kredit ke dalam Dupak (Daftar Pengusul Penetapan Angka Kredit). Setelah berkas siap, dosen mengajukan surat pengantar dari pimpinan STMIK Widuri, pengajuan surat pengantar diberikan ke sekjur untuk disetujui oleh pimpinan. Pada tahap ini baik itu dari Sekjur dan pimpinan tidak melakukan pemeriksaaan lebih lanjut perihal kinerja dosen yang akan mengurus jabatan akademik. Hal ini dikarena pihak perguruan tinggi tidak pernah melakukan penilaian mengenai kinerja dosen, dan otomatis tidak memiliki data yang terkait dengan kinerja dosen. Setelah pimpinan menerima mengajukan tersebut dan menyetujuinya, surat pengantar dikembalikan ke Sekjur untuk diberikan ke dosen yang bersangkutan. Dosen menerima surat pengantar yang telah disetujui oleh pimpinan perguruan tinggi, dan kemudian dosen mengajukan berkas yang terkait dengan pengurusan jabatan akademik dan Dupak untuk diberikan ke kopertis untuk penetapan PAK (Penetapan Angka Kredit).

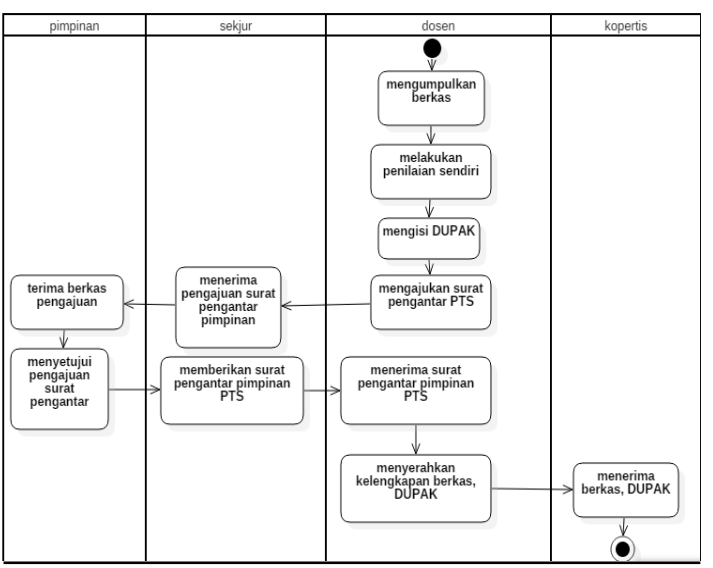

Gambar 1.Analisis Sistem Yang Berjalan

\subsection{Rancangan Activity Diagram}

1. Activity Diagram Login

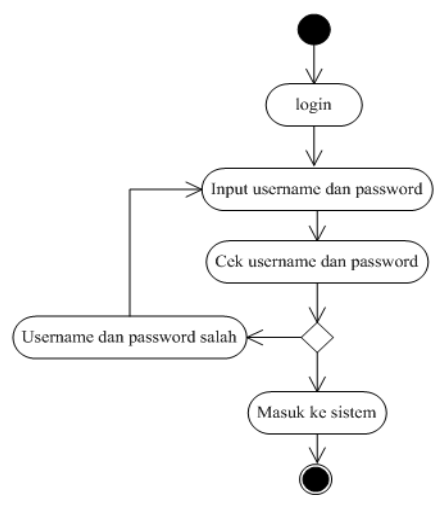

Gambar 2. Activity Diagram Login

- Pengguna melakukan login dahulu untuk mengakses prototipe KMS.

- Setelah memasukkan nama pengguna dan password, maka sistem akan mengecheck yang diinput. Jika berhasil maka pengguna akan menuju halaman utama dan jika data user tidak ditemukan, maka akan muncul error message dan mengharuskan pengguna memasukkan kembali username dan password yang benar.

2. Activity Diagram Master Data 


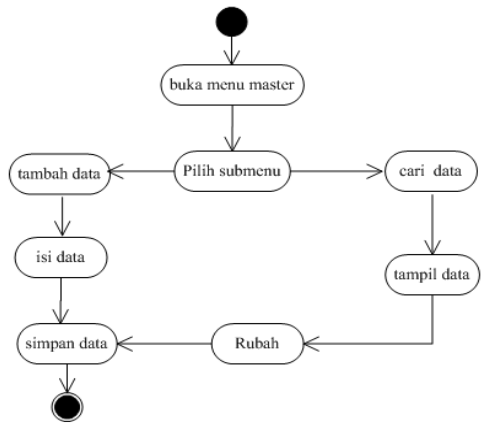

Gambar 3. Activity Diagram Master Data

- Admin memilih menu master data dan akan terbuka beberapa submenu.

- Di setiap submenu tersebut, admin dapat menambah master data baru dan menyimpannya.

- Admin juga dapat mencari master data yang sudah tersimpan di sistem untuk dilakukan perubahan data tersebut.

3. Activity Diagram Input Dokumen

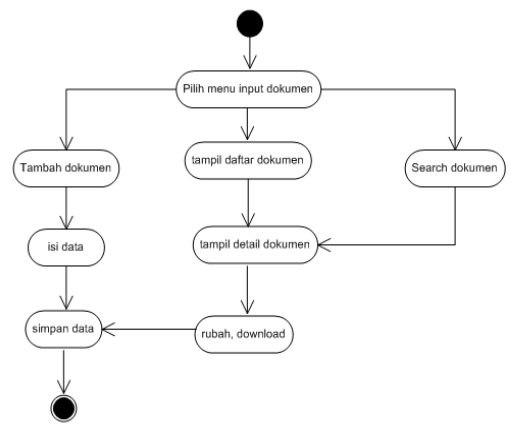

Gambar 4. Activity Diagram Input Dokumen

- Admin dan user memilih menu Input Dokumen.

- Di menu tersebut, admin dan user dapat menambah, mengedit dan mengubah data baru dan menyimpannya.

- Admin dan user juga dapat mencari data yang sudah tersimpan di prototipe untuk dilakukan perubahan data tersebut.

4. Activity Diagram Approval

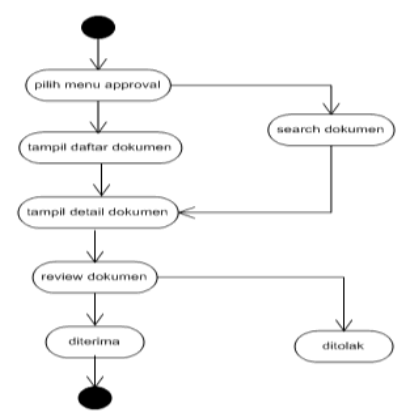

Gambar 5. Activity Diagram Approval

- Admin memilih menu Approval .
- Di menu tersebut, admin dapat mencari, melihat, mereview, mereject atau memberikan approval .

5. Activity Diagram Report

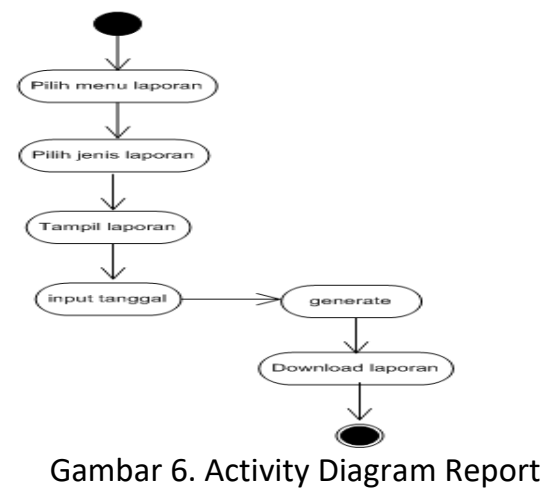

- Admin dan dosen memilih menu Report .

- Di menu tersebut, admin dan dosen dapat melihat dan mendownload laporan yang tersedia.

\subsection{Rancangan Class Diagram}

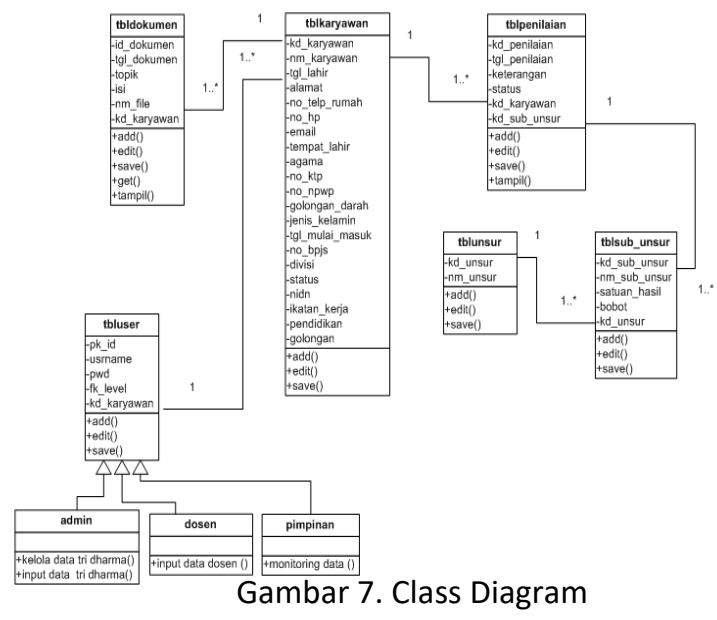

\subsection{Rancangan Antar Muka Level Admin}

a. Form Login

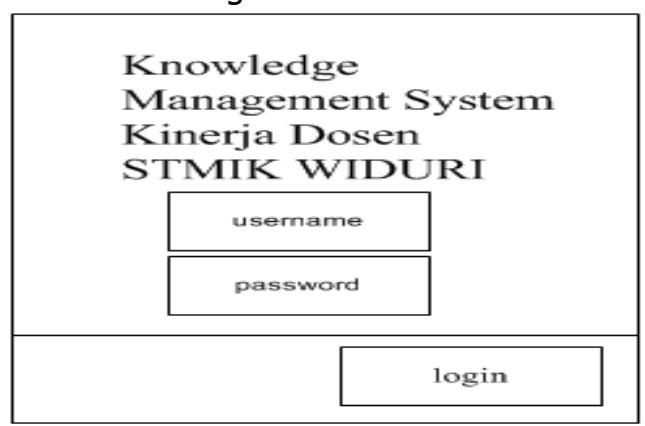

Gambar 8. Form Login

b. Input Data User 


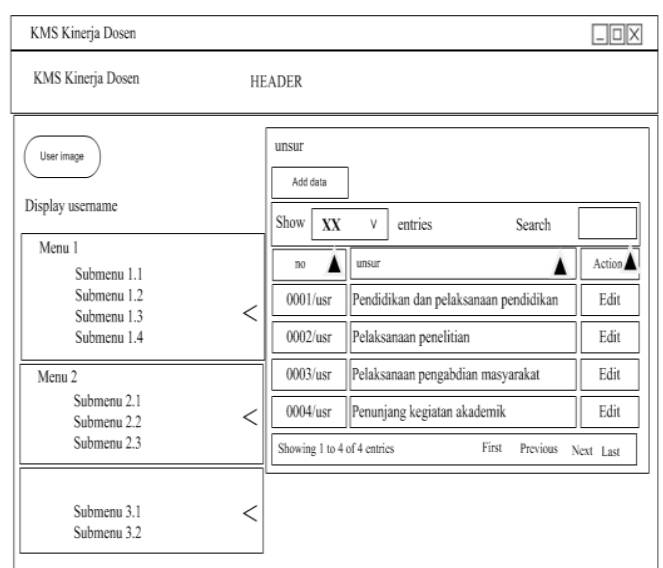

Gambar 9. Input Data User

\section{c. Input Data Sub Unsur}

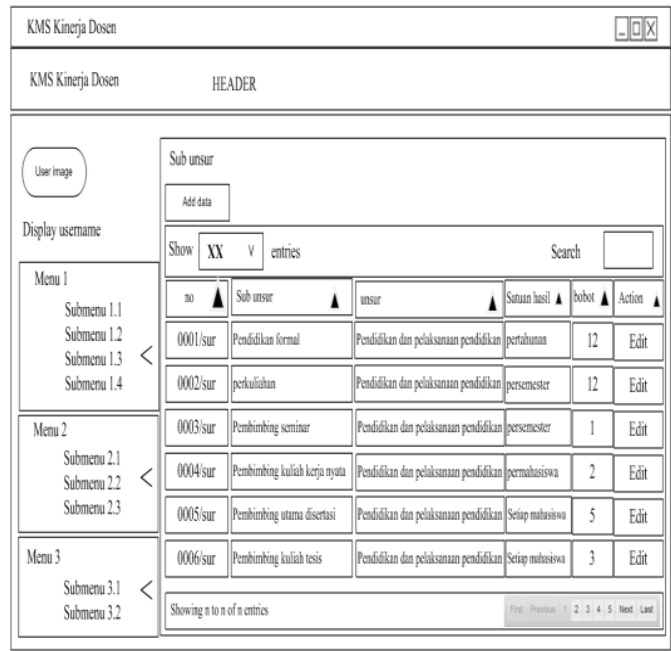

Gambar 10 Input Data Sub Unsur

\section{d. Form Penilaian}

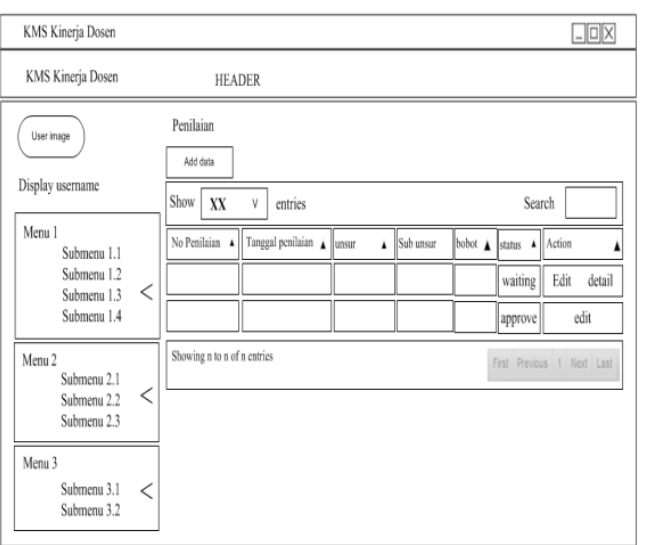

Gambar 11 Form Penilaian

a. Grafik Penilaian

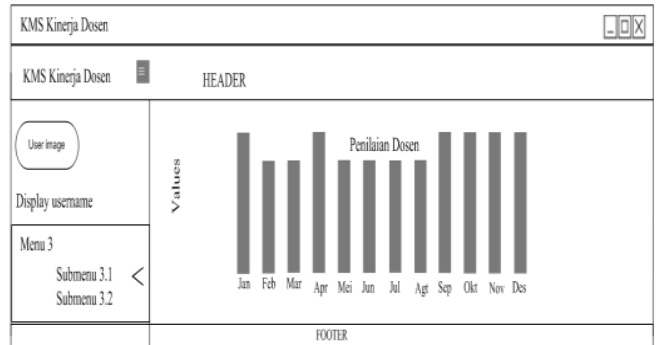

\subsection{Hasil Pengujian Validasi}

Pada tahapan pengujian validasi ini dilakukan untuk memastikan perangkat lunak yang dibuat sesuai dengan kebutuhan fungsional yang diharapkan. Hal ini juga menguji hipotesis pertama dalam penelitian ini yaitu :

a. Hasil Pengujian User Acceptance Test

Berdasarkan UAT selanjutnya dapat direkapitulasi hasil pengujian dari responden dalam Gambar 12. Grafik Penilaian UAT.

Tabel 1. Pilihan Jawaban

\begin{tabular}{|l|l|}
\hline A & Sangat : Mudah/Bagus/Sesuai/Jelas \\
\hline B & Mudah : Bagus/Sesuai/Jelas \\
\hline C & Netral \\
\hline D & Cukup : Sulit/Bagus/Sesuai/Jelas \\
\hline E & $\begin{array}{l}\text { Sangat : Sulit/Jelek/Tidak Sesuai/Tidak } \\
\text { Jelas }\end{array}$ \\
\hline
\end{tabular}

Tabel 2. Hasil Pengujian Validasi

\begin{tabular}{|c|c|c|c|c|c|c|c|c|c|}
\hline \multirow{2}{*}{$\begin{array}{l}N \\
0\end{array}$} & \multirow[b]{2}{*}{ Pertanyaan } & \multicolumn{5}{|c|}{ Jawaban } & \multirow[b]{2}{*}{$\begin{array}{c}\mathrm{Jm} \\
\mathrm{I}\end{array}$} & \multirow[b]{2}{*}{$\begin{array}{c}\text { Analisa } \\
\text { (jml/12 } \\
\text { ) }\end{array}$} & \multirow[b]{2}{*}{$\%$} \\
\hline & & $\begin{array}{l}A \\
x \\
5\end{array}$ & $\begin{array}{l}B \\
x\end{array}$ & $\begin{array}{l}C \\
x\end{array}$ & $\begin{array}{l}D \\
x\end{array}$ & $\begin{array}{l}E \\
x\end{array}$ & & & \\
\hline 1 & $\begin{array}{l}\text { Apakah } \\
\text { tampilan } \\
\text { prototype KMS } \\
\text { ini menarik? }\end{array}$ & 0 & 0 & $\begin{array}{l}2 \\
1\end{array}$ & 0 & 0 & 41 & 3,42 & $\begin{array}{l}68, \\
4\end{array}$ \\
\hline 2 & $\begin{array}{l}\text { Apakah menu- } \\
\text { menu pada } \\
\text { prototype KMS } \\
\text { ini mudah } \\
\text { dimengerti dan } \\
\text { dipahami? }\end{array}$ & $\begin{array}{l}3 \\
0\end{array}$ & 0 & 3 & 0 & 0 & 53 & 4,42 & $\begin{array}{l}88, \\
4\end{array}$ \\
\hline 3 & $\begin{array}{l}\text { Apakah } \\
\text { prototype KMS }\end{array}$ & 0 & 1 & 1 & 6 & 0 & 37 & 3,08 & 61, \\
\hline
\end{tabular}




\begin{tabular}{|c|c|c|c|c|c|c|c|c|c|}
\hline . & $\begin{array}{l}\text { dapat diakses } \\
\text { dengan mudah } \\
\text { dimanapun? }\end{array}$ & & 6 & 5 & & & & & 6 \\
\hline 4 & $\begin{array}{l}\text { Apakah menu } \\
\text { pada prototype } \\
\text { KMS yang } \\
\text { tersedia dapat } \\
\text { memudahkan } \\
\text { untuk } \\
\text { memperoleh } \\
\text { informasi yang } \\
\text { dibutuhkan? }\end{array}$ & $\begin{array}{l}1 \\
5\end{array}$ & $\begin{array}{l}2 \\
4\end{array}$ & 9 & 0 & 0 & 48 & 4,00 & 80 \\
\hline 5 & $\begin{array}{l}\text { Apakah menu- } \\
\text { menu yang } \\
\text { tampil, sudah } \\
\text { dipisahkan } \\
\text { berdasarkan } \\
\text { level masing - } \\
\text { masing user? }\end{array}$ & $\begin{array}{l}4 \\
0\end{array}$ & $\begin{array}{l}1 \\
6\end{array}$ & 0 & 0 & 0 & 56 & 4,67 & $\begin{array}{l}93, \\
4\end{array}$ \\
\hline 6 & $\begin{array}{l}\text { Apakah } \\
\text { prototype KMS } \\
\text { ini sudah dapat } \\
\text { merekam } \\
\text { knowledge } \\
\text { dosen? }\end{array}$ & $\begin{array}{l}4 \\
5\end{array}$ & 4 & 6 & 0 & 0 & 55 & 4,58 & $\begin{array}{l}91, \\
6\end{array}$ \\
\hline 7 & $\begin{array}{l}\text { Apakah } \\
\text { prototype KMS } \\
\text { ini dapat } \\
\text { membantu } \\
\text { administrator } \\
\text { dalam } \\
\text { memonitoring } \\
\text { progress } \\
\text { knowledge? }\end{array}$ & $\begin{array}{l}3 \\
0\end{array}$ & $\begin{array}{l}1 \\
6\end{array}$ & 6 & 0 & 0 & 52 & 4,33 & $\begin{array}{l}86, \\
6\end{array}$ \\
\hline 8 & $\begin{array}{l}\text { Apakah sudah } \\
\text { terdapat menu } \\
\text { laporan untuk } \\
\text { knowledge } \\
\text { dosen secara } \\
\text { keseluruhan? }\end{array}$ & 0 & $\begin{array}{l}2 \\
0\end{array}$ & 5 & 4 & 0 & 35 & 2,92 & 59 \\
\hline 9 & $\begin{array}{l}\text { Apakah sistem } \\
\text { ini dapat } \\
\text { mengukur } \\
\text { knowledge } \\
\text { dosen? }\end{array}$ & 5 & $\begin{array}{l}2 \\
8\end{array}$ & 2 & 0 & 0 & 45 & 3,25 & 65 \\
\hline 0 & $\begin{array}{l}\text { Apakah } \\
\text { prototype KMS } \\
\text { ini sudah cukup } \\
\text { baik? }\end{array}$ & 0 & $\begin{array}{l}2 \\
0\end{array}$ & 2 & 6 & 0 & 38 & 2,83 & 68 \\
\hline \multicolumn{7}{|c|}{ Total } & $\begin{array}{l}46 \\
0\end{array}$ & 38,33 & $\begin{array}{l}76, \\
2\end{array}$ \\
\hline
\end{tabular}

Kesimpulan Hasil Pengujian Validasi

Berdasarkan hasil UAT, maka dapat disimpulkan bahwa hasil analisa, prototype KMS kinerja dosen untuk jabatan akademik secara fungsional diterima oleh pengguna dengan bobot $76,2 \%$, aplikasi ini dapat berfungsi memberikan solusi bagi STMIK Widuri dalam hal pendokumentasian yang terkait dengan jabatan akademik dosen, hal ini juga menguji hipotesis diduga kualitas dari KMS jika di uji dengan user acceptance test adalah baik.

\section{Kesimpulan}

Dari pembahasan pada bab-bab sebelumnya dapat disimpulkan beberapa hal sebagai berikut :

Melalui knowledge management system dapat meningkatkan kinerja dosen untuk jabatan akademik.

Portal knowledge management system memudahkan untuk mengelola data kinerja dosen yang menunjang jabatan akademik tersimpan beberbentuk digital dan lebih terstruktur.

\section{DAFTAR PUSTAKA}

Abdul, K. 2014, Pengenalan Sistem Informasi Edisi Revisi. Andi Offset, Yogyakarta.

Adi, N, 2005, Rekayasa Perangkat Lunak Menggunakan UML dan Java, Andi Offset, Yogyakarta.

Ari, F.S., Iping, Supriana., 2014, Kridanto, Surendro, Knowledge Management di UKM, Jurnal IImiah Teknologi Informasi Terapan, Vol.1 No.1 2407-3911.

Dave, Yates dan Scott, Paquette, 2010, Emergency Knowledge Management and Social Media Tecnologies : A Case Study of The 2010 Haitian Eartquake, International Journal of Information Management, 31:6-13, Elevier Ltd, United States.

Hanif, F. 2007, Analisis dan Perancangan Sistem Informasi Untuk Keunggulan Bersaing Perusahaan dan Organisasi Modern, Andi Offset, Yogyakarta . 
Irma, B.F dan Rajiv, Sabherwal, 2010, Knowledge Management System and Processes, M.E.Sharpe, Inc, New York.

Indrajani. 2014, Pengantar Sistem Basis data Case Study All In One. Elex Media Komputindo, Jakarta.

Kuswandi, 2016, Prototipe Knowledge Management System Materi Perkuliahan, Jurnal Lentera ICT, Vol.3 No.1 2338-3143.

Mariana, Simanjuntak, 2011, Manajemen Pengetahuan Dalam Perguruan Tinggi, Manajemen Balanced Scorecard di Peguruan Tinggi.

Raymond, M dan George, S.P. 2007, Sistem Informasi Manajemen, Edisi 10, Salemba Empat, Jakarta.

Rainer, Rambi., Victor, P.K.L., Rotinsulu, J.P, 2015, Pengaruh Praktek - Praktek Manajemen Sumber Daya Manusia Terhadap Kinerja Pegawai pada PT.PLN (Persero) Wilayah Sulutenggo, Jurnal Berkala Ilmiah Efisiensi, Vol.15 No.5 $622-634$.

Riswan, E.T., Andree, E.W., Hery, Hery, 2017, Pengaruh Penerapan Knowledge Management System terhadap Efektivitas Kinerja Karyawan : Studi Kasus Pada Sebuah Perusahaan Telekomunikasi, Seminar Nasional Inovasi dan Aplikasi Teknologi Di Industri, Malang, 2085-4218.

Risky, T.B., M.J.D, Sunarto., 2012, Tri, Sagirani, Rancang Bangun Aplikasi Knowledge Management Multimedia Dalam Proses Pengembangan Video Pendidikan Pada BPMTV Surabaya, Jurnal JSIKA, Vol 1 No.1.

Sudaryono, 2015, Metodologi Riset di Bidang IT : Panduan Praktis, Teori dan Contoh Kasus, Edisi 1, Andi Offset, Yogyakarta, Indonesia.
Sugiarti, 2012, Analisis dan Perancangan UML (Unified Modelling Language) Generated VB.6 Disertai Contoh Studi Kasus dan Interface Web, Graha IImu, Jakarta. 